International Research Journal of Engineering, IT \& Scientific Research
Available online at https://sloap.org/journals/index.php/irjeis/
Vol. 7 No. 3, May 2021, pages: 97 -106
ISSN: 2454-2261
https://doi.org/10.21744/irjeis.v7n3.1539

\title{
Specific Learning Difficulty: Autism, Dyscalculia, Dyslexia and Dysgraphia
}

\author{
Karina Eliana Castro Intriago ${ }^{\text {a }}$ \\ Liliana Magdalena Alcívar Rodríguez ${ }^{\text {b }}$ \\ Luis Alfredo Tubay Cevallos ${ }^{c}$
}

\section{Article history:}

Submitted: 18 February 2021

Revised: 27 March 2021

Accepted: 9 April 2021

\section{Keywords:}

autism;

dyscalculia;

dysgraphia;

dyslexia;

specific learning difficulties;

\section{Corresponding author:}

Intriago, K. E. C.

Pontificia Universidad Católica del Ecuador, Portoviejo, Manabí, Ecuador

Email address: kcastro9281@pucesm.edu.ec

\begin{abstract}
There are specific learning difficulties such as autism, dyscalculia, dyslexia and dysgraphia, the purpose of this article is to understand how these disorders affect verbal, non-verbal, logical and written communication in the social relationships of children who suffer from it. The qualitative methodology was applied in combination with the desk review technique, obtaining clear and pertinent criteria, an analysis of concepts was proposed on each of their meanings, characteristics and typology, suggestions of learning techniques are presented regarding the way correct to reduce disorders, the opinion of different authors who have carried out studies on the subject was obtained, interpreting from the pedagogical perspective and the importance of knowing the subject to act against these learning problems.
\end{abstract}

International research journal of engineering, IT \& scientific research (C) 2021. This is an open access article under the CC BY-NC-ND license (https://creativecommons.org/licenses/by-nc-nd/4.0/).

a Pontificia Universidad Católica del Ecuador, Portoviejo, Manabí, Ecuador

b Pontificia Universidad Católica del Ecuador, Portoviejo, Manabí, Ecuador

c Pontificia Universidad Católica del Ecuador, Portoviejo, Manabí, Ecuador 


\section{Introduction}

For years it has been considered that learning problems were simply stages where children did not want to learn or study, the reasons and causes for which there were difficulties were unknown, as well as effective solutions through direct intervention to the problem or object of study, at present the infinity of investigations and scientific studies allow us to know that they are conflicts with affectations in the brain and how to process information to acquire the necessary skills and apply them in the context of their life (Hall, 2008; Jongmans et al., 1996).

A Specific Learning Difficulty (DEA) is an inadvertent, constant and continuous disorder that prevents the acquisition of normal knowledge in the construction of contents when they enter the brain, being disorders studied by neuroscience.

It should be remembered that a child with AED has problems when entering, retaining and executing the content received and / or provided by third parties, it is significant to find the methods and strategies that allow them to comply with their cognitive process, it must be detected and addressed in time what type of disorder does it have, in what degree or stage it is found, how to overcome or improve the quality of life of those who suffer from any type of these, it is necessary to carry out an adequate medical, psychological and pedagogical complete diagnosis, although it is not yet known has managed to determine its cause exactly, it is related to a brain injury (Ramírez, 2011; Nightingale et al., 2019; Richardson \& Puri, 2002).

The reality experienced by the students are many, to overcome this type of disorder for the most part, it is necessary that there exist around these infants trained people, understood in the problem that they exercise with full knowledge of the cause, techniques and therapies that promote learning, as well as the development of motor skills according to the capacity of each person involved and their particular way of receiving information in their brain.

AEDs are permanent and repeated, based on treatments and therapies, strategies are found to improve their cognitive learning style, they can overcome in most cases their difficulty and they manage to develop as professionals in their adulthood, usually a child who suffers from some difficulty possesses innate skills and talents in other areas (Hudson, 2017).

\section{Materials and Methods}

For this research, a qualitative methodological strategy was carried out, in combination with the desk research technique (Díaz, 2018), to review documents where specific learning difficulties are explained, what they are and how they affect life of a child for their integral and complete holistic development, the nature of the topic was considered in itself to determine the most pertinent approaches with clear and concrete criteria, analytically synthesized. Documentary research is a scientific technique of an orderly process of search, collection, synthesis and paraphrase of information or data on the subject matter (Rizo, 2015; Woodcock \& Vialle, 2016; Woodcock et al., 2019).

The context is analyzed on how they have highlighted the deficit in being diagnosed, with the documentary review of sources obtained from indexed web pages, articles or digital repositories, as well as virtual libraries that allow information to be collected and to reach clear, concrete results with pertinent senses objectively detailed and framed in the development of their capacities.

\section{Results and Discussions}

Understand how it implies an execution of contents and motor skills learned throughout life by the child's environment where it demonstrates the development of what he speaks, writes or practices, allowing to expose the ability to learn and develop skills and abilities (Shunk, 2012), occurs when new information enters the brain and is fully developed by receiving content that is transmitted by the teacher or guide.

People acquire information through the visual, auditory and kinesthetic senses (VAK), although in most cases each person tends to develop and use more of one type of learning, it must be taken into account that the union of these three executes the assimilation of content (Hudson, 2017). The educational process follows a planning and a guideline with methods and strategies that generate interest, as well as the techniques that are applied achieve the complete, holistic development of the person and their versatility in terms of their innate skills and talents (Armas, 2019). 
Learning in people with specific difficulties occurs in a slow, different and progressive way, it must be borne in mind that each individual has their own rhythm to assimilate and that is how addressing these AEDs allows us to discover at what stage to diagnose and suggestions for techniques of teaching for cognitive development, Table 1 shows the types of difficulties and their diagnoses.

Table 1

Types of difficulties and their diagnosis

\begin{tabular}{cc}
\hline Types of Difficulties & Diagnosis \\
\hline Autism & $\begin{array}{c}\text { Delays in speech and language skills. Repeating words or } \\
\text { phrases over and over (echolalia). }\end{array}$ \\
Dyscalculia & $\begin{array}{r}\text { Confusion in numbers and signs, does not perform mental } \\
\text { calculations or abstractions. } \\
\text { Pyslexia and Dysgraphia }\end{array}$ \\
\hline
\end{tabular}

\section{Autism}

The conceptualization of the so-called autism has varied greatly since its first scientific investigation in 1943 by the Austrian researcher Leo Kanner. Currently it is defined as "Autism Spectrum Disorders" (ASD), it is derived from the Greek word autos = means oneself, or living according to oneself, given the variable cognitive and language impairment, it is set as a subgroup within of generalized developmental disorders (Mulas, Téllez, Etchepareborda, Cervera, Millá and Abad, 2010).

It is analyzed as a permanent and profound neurological disorder that significantly affects verbal and non-verbal communication and social relationships. Some clinical phenotypes are identified such as: Asperger's Disorder, Infantile Disintegrative, Generalized Developmental Unidentified and Rett Syndrome, therefore, autism can be defined as a group that has three aspects in common: alteration of sociability, communication verbal and non-verbal and restricted interests (Sánchez, Sánchez, Pastor and Martínez, 2019),

Children with ASD, present a syndrome characterized by alterations in social communication, alterations in behavior and cognitive development, this is called as a profound developmental learning disorder (Schneider, 2017). This learning disorder can be detected between two and three years of life of a child, it is characterized by deficiencies, alterations and delay at the level of language and verbal and non-verbal communication, the repetitive action of physical movements, echolalia and its games are functional and symbolic (Olivos, 2017). Likewise, alterations in social development, especially interpersonal reciprocity, alterations in thought and behavior, poor social imagination, perseverance and delay (Benites, 2010). García (2016), classifies generalized developmental disorders into five types, common elements that allow the differential diagnosis between the different disorders, presented in Figure 1.

Intriago, K. E. C., Rodríguez, L. M. A., \& Cevallos, L. A. T. (2021). Specific learning difficulty: autism, dyscalculia, dyslexia and dysgraphia. International Research Journal of Engineering, IT \& Scientific Research, 7(3), 97-106. 


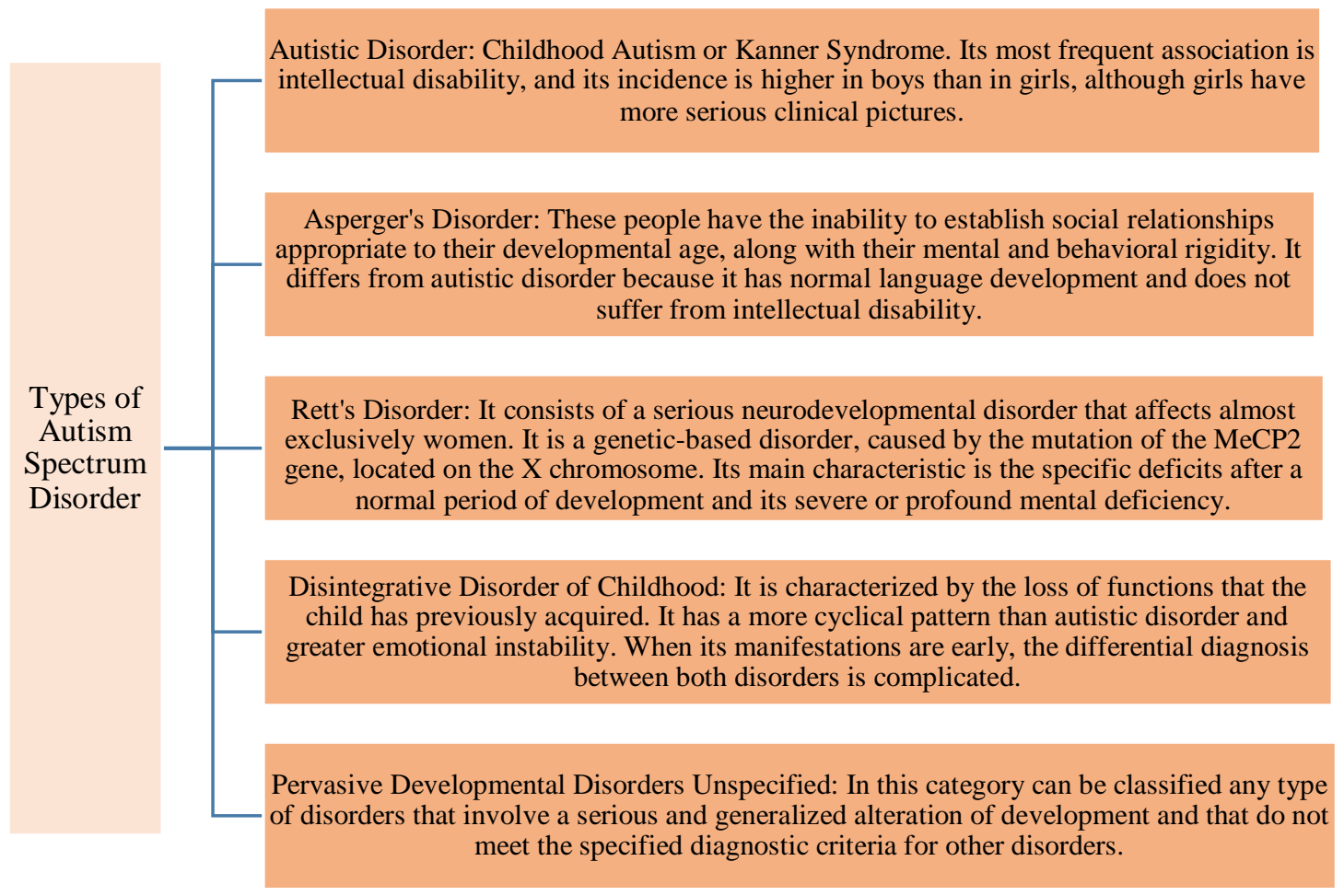

Figure 1. Types of autism spectrum disorders

The treatments for people with ASD are varied and complex and requires professionals trained in the field of neurological, pedagogical and psychological knowledge, in different environments, this will allow to know each case with accuracy. A very common characteristic among people who have autism spectrum disorders is the high or low sensitivity of the environment and the difficulty to communicate. Martínez and Arroyo (2016), have classified occupational therapies as follows:

- Sensory integration. - It aims to integrate the information that reaches your brain and thus improve your daily life.

- Contextual intervention. - The purpose is to know the entire environment of the person affected with the ASD in order to improve their conditions in society.

- Human occupation model. - The objective is to improve communication at an early age and their personal autonomy.

- Other disciplines, of occupational therapies. - It is reflected from the sensory integration; the model of human occupation and contextual intervention is applied.

The family plays a fundamental role in the treatment of ASD, it favors the learning of behavior by offering models, establishing a schedule, reducing noise, offering reading strategies and other learning and behavior habits. The school is considered as a functional complement that contributes in the construction of co-responsible knowledge of the skills to be developed, the school contents must be organized, systematized and presented through a logical teaching sequence (Benítez, Catalá \& Domeniconi, 2016), the role of teacher focuses on intervening in the weakest point of children with autism, communication, language and motor skills, should not diagnose or medicate, that's what specialists and therapists are for.

Treatment with medication in people with this disorder is a complex issue, currently new studies and psychological treatments are used that include training programs for verbal, social and pharmacological behaviors, these attenuate symptoms of insomnia, self-harm, behavior problems, irritability, impulsivity, anxiety or depression, hyperactivity, etc. (Aragunde, Rodríguez, Fontenla and Pazos, 2018). Children with autism have a different way of perceiving the world and processing the information they receive from the external environment, knowing this is 
essential to develop any curricular plan with them, always trying to take advantage of these special characteristics to be able to teach them things in a way effective (Rangel, 2017).

\section{Dyscalculia}

Dyscalculia or well called mathematical dyslexia, is a specific learning difficulty in the area of calculation, it comes from the Greek dis = difficulty and from the Latin calculia = calculate, which means to calculate or count, being difficult to understand and perform arithmetic exercises, understand the abstract and follow a sequential order of numerical type, it is the alteration that a subject presents in the processes Mathematicians, it is difficult for the person to recognize symbols, develop operations, learn and put into practice formulas, identify numbers, among others. There are several factors that can be direct causes of the difficulties presented to satisfy the academic demands that occur in the classroom, for example, performing basic operations such as adding and subtracting (Barba, Pérez and Bedón, 2018).

This specific learning difficulty affects a percentage of the child population between $3 \%$ and $6 \%$, they present alterations in the functioning of the brain areas responsible for learning and process mathematical information in a special and different way, it is common to find in The initial levels of students with notable deficiencies in the calculation and who have dyscalculia, is manifested when the arithmetic capacity is substantially below that expected in individuals with an IQ and schooling according to their age (Fonseca, López and Massagué, 2019). Operation in mathematics requires having developed numerical skills in the first years of academic instruction, but such skill is lagged in students who are diagnosed with dyscalculia, a situation that prevents them from keeping up with the group of peers who find no difficulty in understanding processes arithmetic.

The educational community must be committed to supporting students with dyscalculia, they require clear, detailed information and a set of strategies and techniques for the implementation of an education that is best suited to students with these disorders, whose ultimate goal It is based on developing their capacities and abilities to the maximum (Teruel and Latorre, 2014). Six types of dyscalculia that could occur in isolation or in combination were established Kosc (1974), these are presented in Figure 2.

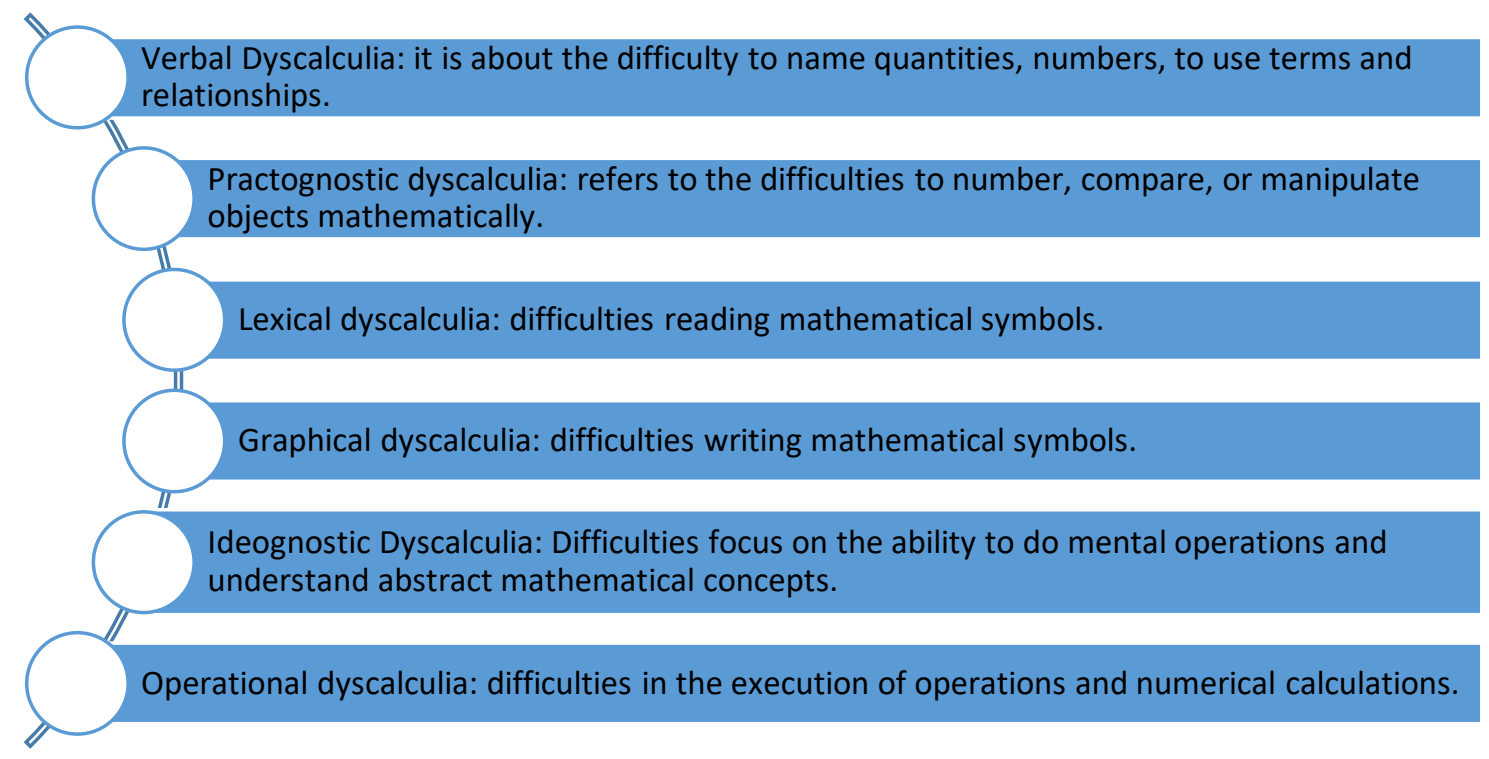

Figure 2. Types of dyscalculia

Mathematical understanding is closely linked to cognitive development. Here is the importance of the maturation of brain structures, so that certain mathematical concepts can be learned and applied in everyday life, generating meaningful learning and not something for the moment that tends to be forgotten, stimulating the left hemisphere where the mathematical logical capacity is stored to avoid disinterest in this area of knowledge that gives way to the increase of dyscalculia in students (Fernández, 2010).

Intriago, K. E. C., Rodríguez, L. M. A., \& Cevallos, L. A. T. (2021). Specific learning difficulty: autism, dyscalculia, dyslexia and dysgraphia. International Research Journal of Engineering, IT \& Scientific Research, 7(3), 97-106. https://doi.org/10.21744/irjeis.v7n3.1539 
Rojas, Contreras and Arévalo (2011), point out that mathematical understanding works from definitions, calculations and operations, this interaction of knowledge with other realities is considered a process of abstraction and can occur through the following couplings of:

- Adaptation: knowledge Mathematical that is possessed is applied to the reality under study or contributes to its development.

- Modeling: Mathematics studies reality, creating models from the knowledge that is possessed.

- Resurgence: Mathematical knowledge is recognized in the behavior of realities.

These learning techniques to help a child with dyscalculia, allow a dual segregation with the way the brain deals with basic mathematics and the loss of abilities to remember elementary arithmetic procedures in cognitive processes (Alonso, 2009).

\section{Dyslexia and Dysgraphia}

These specific learning difficulties are characterized by problems when recognizing letters, syllables or phrases accurately, fluently and misspelling an orthographic writing, coming from the Greek words dis = difficulty and lexis $=$ speech or diction, being difficulty in the language; and dis $=$ difficulty and spelling $=$ writing, being the writing difficulty.

Dyslexia is a learning disorder that manifests itself with the alteration of the reading-comprehension acquisition, it is characterized by a severe and specific difficulty to acquire reading levels in relation to other cognitive abilities of the subject, this difficulty is very noticeable in the children for their development in reading, writing, spelling and counting (Fratini, 2017). Dysgraphia is a learning difficulty of the lesser known, identified and treated, it presents problems with the ligaments, nerves and tendons between the arm and the hand, its level of intelligence is not affected, but its agreement when presenting content written (García, Madrazo and Viñals, 2002).

Francisco Mora in his conference "we are what education makes of us" of the year 2018 issues his criteria on the child's learning and his ability to convert a grapheme to phoneme, it is developed in some of the cases between 5 and 6 years, in others from 7 years of age. The neuro scriptural and reader system is complex, they go hand in hand because the functions of reasoning and abstracting must work together, discriminate phonological graphics, coordinate the ocular-manual sense to give rise to writing and finally recognize written letters (Rodríguez, 2015).

It has been proven by neuroeducation and scientific research that certain areas of the brain between the posterior parietal cortex and superior temporal cortex develop the ability to write and read, thanks to the fact that the synaptic circuits are complete, these being in conjunction with the frontal and occipital lobes the that complete the neuro scriptural and reader system. According to studies, the first scribbles are developed in childhood, from 15 to 24 months a pencil begins to maneuver against a paper imitating what they see around them, from 3 to 5 years they make lines, paint and show interest in writing their name, from there until the age of 7 formal writing begins, presenting at this stage its disorder or omission in the writing of syllables and letters, being more evident in $60 \%$ in boys than in girls dysgraphic confusion (Scrich, Cruz, Bembibre and Torres, 2017). The differences between two types of dyslexia are raised according to Tamayo (2017), these are presented in Figure 3. 
In the case of phonological dyslexia, the person shows difficulties in the grapheme-phoneme conversion mechanism, which is why they tend to use the lexical route. The reading of familiar words is accurate, but they show difficulties in reading pseudowords and unfamiliar words.
Types of Dyslexia
Phonological dyslexia
In the case of superficial dyslexia, they tend to use the phonological pathway so they are usually unable to recognize the word as a whole. In this case the execution is accurate in regular words (regardless of familiarity), and pseudowords.

Figure 3. Types of dyslexia

Source: Tamayo (2017)

Understand that in some cases dysgraphia is presented by lateralization problems and psychomotor deficiency or with graphic expression of language, it is also shown in children with affective or emotional conflicts, due to having phobias or pictures of discomfort, fright, fear or anxiety, among others. Portellano (2014), divides two types of dysgraphia as shown in Figure 4.

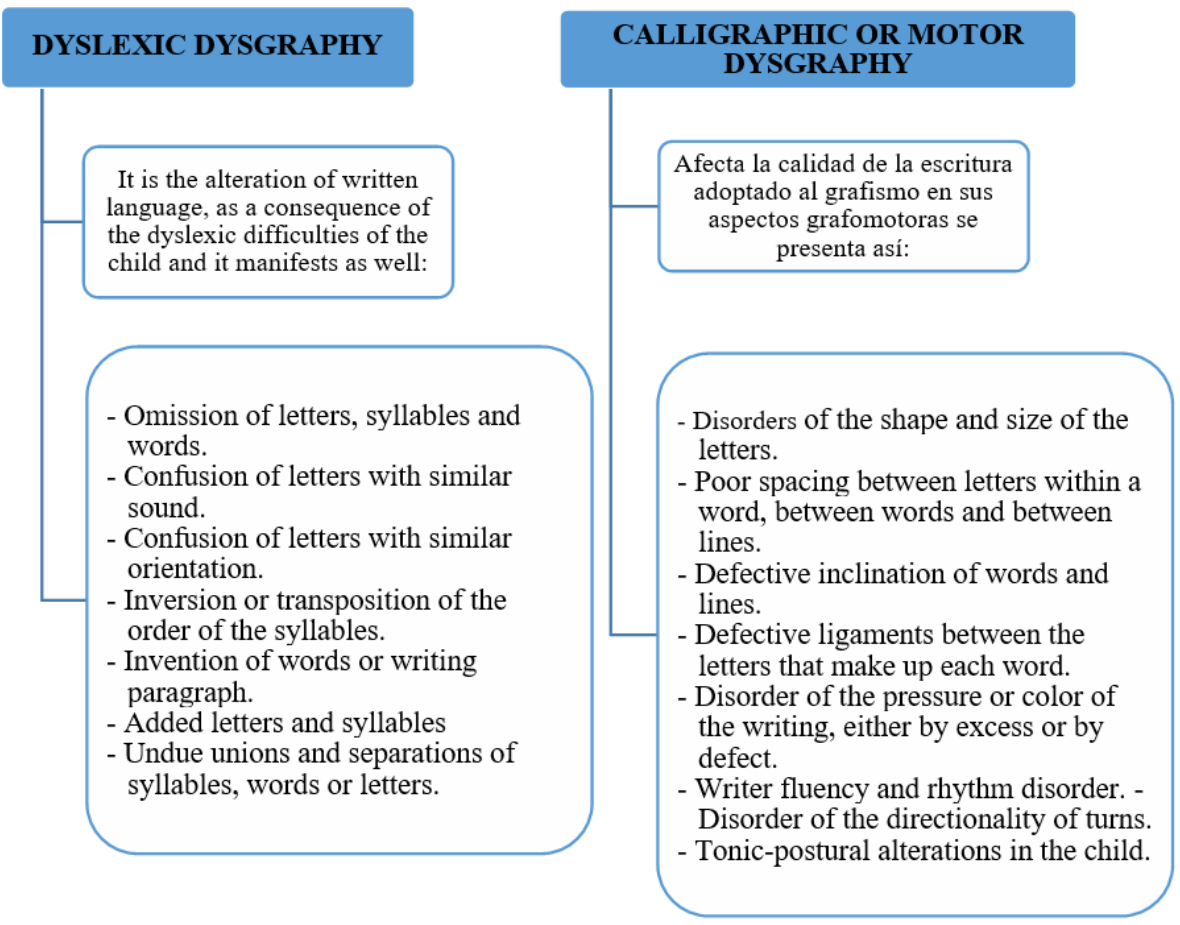

Figure 4. Types of dysgraphia

Source: Portellano (2014)

It is necessary to know in what degree of dyslexia and dysgraphia children are, the causes that cause this disorder of learning, carry out a total diagnosis that involves the clinical history, studies of the infant's personality and neuropsychological studies, to correctly assess and determine each of its functions in depth (Portellano, 2014).

Intriago, K. E. C., Rodríguez, L. M. A., \& Cevallos, L. A. T. (2021). Specific learning difficulty: autism, dyscalculia, dyslexia and dysgraphia. International Research Journal of Engineering, IT \& Scientific Research, 7(3), 97-106. 
Within the clinical history, the control of pregnancy and birth, follow-up of development in its stages, crawling, first steps, control of clamps and sphincters should be taken into account, if there is any pre-existing disease, among others. On the other hand, in the neuropsychological and pedagogical study it is carried out to discover the mental age and that coincides with its chronological age, it is recommended to perform the Wechsler, Bender or Santucci tests, these allow to identify the level of aptitude and performance according to a representative scale, discovering the dominant laterality and visual perception allowing to measure the reading degree since in $70 \%$ of cases the difficulty of reading and writing is presented together (Portellano, 2014).

At present there are learning techniques and methods for reeducation, dysgraphic and dyslexic correction that allow to obtain changes in reading and writing, using cognitive, motor and functional system reorganization, among the methods to be applied are those of Ajuriaguerra that focuses In treating personal emotions and motor skills, while Brueckner's method focuses on the pedagogy of continuous practice exercises (Portellano, 2014), a correct judgment of literacy must be possessed, it must intervene in the modifications of omissions, spaces, among others, motor skills exercises, dictation and visual semantic keys, always in the hands of specialized and knowledgeable people in these types of disorders.

\section{Conclusion}

Once the analytical documentary research has been carried out, it can be determined that specific learning difficulties only have an improvement in the quality of life of those who suffer them, with the aim of maximizing the ability to function in a quiet environment and bring out their cognitive development and Social. Teachers cannot diagnose specific learning difficulties, children must access and discover by themselves the environment in which they are immersed, acquire their skills and abilities where they can internalize phonemes, graphemes, execute writing and calculation exercises, under the supervision of specialized personnel.

\section{Conflict of interest statement}

The author(s) declared that they have no competing interest.

\section{Statement of authorship}

The author(s) have a responsibility for the conception and design of the study. The author(s) have approved the final article.

\section{Acknowledgments}

We are grateful to two anonymous reviewers for their valuable comments on the earlier version of this paper. 


\section{References}

Alonso, D. (2009). Brain, numbers and education. Classroom: Pedagogy Magazine of the University of Salamanca, (15), 79-90. Retrieved from https://dialnet.unirioja.es/servlet/articulo?codigo=3094486

Aragunde, P., Rodríguez, J., Fontenla, E., Pazos, J. (2018). Autism and the role of the teacher in the classroom of motor skills in early childhood education. EmásF: Digital Journal of Physical Education, 53(1), 67-68. Recovered from https://dialnet.unirioja.es/servlet/articulo?codigo $=6482548$

Armas, M. (2019). Make learning flow. International Journal of Developmental and Educational Psychology, 2(1), 299-309. Retrieved from https://www.redalyc.org/articulo.oa?id=349860126029

Barba, P., Pérez, A., Bedón, P. (2018). Learning problems in childhood. Didasc @ lia: Didactics and Education, 9(4), 85-100. Retrieved from https://dialnet.unirioja.es/servlet/articulo?codigo=6716410

Benites, L. (2010). Autism, Family and quality of life. Journal of the Association of Teachers of the USMP, $24(1), 3$. Retrieved from https://dialnet.unirioja.es/servlet/articulo?codigo=3701024

Benitez, P., Catalá, M., Domeniconi, C. (2016). Minors with autism and intellectual disabilities who learn to read and write. Apuntes de Psicología, 34(1), $38 . \quad$ Retrieved from https://dialnet.unirioja.es/servlet/articulo?codigo $=6010842$

Díaz, L. (April 30, 2018). Desk Research and www, effective information at hand. The Republic. Retrieved from https://larepublica.pe/marketing/1377831-desk-research-www-informacion-efectiva-mano/?ref=lre

Eljuri, A. (2016). School inclusion of children with autism spectrum disorder psychoanalytic perspective. Revista San Gregorio, 11, 110. Recovered from https://dialnet.unirioja.es/servlet/articulo?codigo=5585733

Fernández, J. (2010). Neurosciences and Teaching of Mathematics. Ibero-American Journal of Education, (51). Retrieved from https://rieoei.org/historico/expe/3128FdezBravo.pdf

Fonseca, F., López, P., Massagué, L. (2019). Didactic model of treatment of dyscalculia in primary school students. Journal of the Faculty of Physical Culture of the University of Granma, 16(54), 254-268. Recovered from https://dialnet.unirioja.es/servlet/articulo?codigo=6981112

Fratini, V. (2017). Morphological inflectional processing in Spanish-speaking girls and boys with dyslexia. Basque Country University Thesis. Retrieved from https://dialnet.unirioja.es/servlet/tesis?codigo=155652

García, J., Madrazo, M., and Viñals, F. (2002). Alterations in the processing of writing,dysgraphia superficial. Spanish Journal of Neuropsychology, 4(4), 283-300. Recovered from https://dialnet.unirioja.es/servlet/articulo?codigo=1007109

García, P. (2016). Autism Spectrum Disorder (ASD). Annals: Anuario del centro de la UNED de Calatayud, 22(1), 150. Retrieved from https://dialnet.unirioja.es/servlet/articulo?codigo $=6080826$

Hall, A. (2008). Specific learning difficulties. Psychiatry, 7(6), $260-265$. https://doi.org/10.1016/j.mppsy.2008.04.009

Hudson, D. (2017). Specific learning disabilities and other disorders. Narcea Editions. https://elibro.puce.elogim.com/es/lc/puce/titulos/46275

Jongmans, M., Dubowitz, L., Demetre, J. D., \& Henderson, S. E. (1996). How local is the impact of a specific learning difficulty on premature children's evaluation of their own competence?. Journal of Child Psychology and Psychiatry, 37(5), 563-568. https://doi.org/10.1111/j.1469-7610.1996.tb01442.x

Kosc, L. (1974). Developmental dyscalculia. Journal of Learning Disabilities, 7(3), 164-177. Retrieved from https://journals.sagepub.com/doi/10.1177/002221947400700309

Martínez, A., Arroyo, M. (2016). Review of the professional practice of occupational therapy in autism. Occupational electronic magazine Galicia, 24(1), 19-23. Retrieved from https://dialnet.unirioja.es/servlet/articulo?codigo=5789772

Mulas, F., Téllez, M., Etchepareborda, M., Cervera, G., Millá, M., Abad, L. (2010 ). Models of intervention in children with autism. Revista de Neurología 50(3), 78 . Recovered from https://dialnet.unirioja.es/servlet/articulo?codigo $=4223266$

Nightingale, K. P., Anderson, V., Onens, S., Fazil, Q., \& Davies, H. (2019). Developing the inclusive curriculum: Is supplementary lecture recording an effective approach in supporting students with Specific Learning Difficulties (SpLDs)?. Computers \& Education, 130, 13-25. https://doi.org/10.1016/j.compedu.2018.11.006

Olivos, A. (2017). The autistic subject and its edge. Affectio Societatis, 14(26), 79. Recovered from https://dialnet.unirioja.es/servlet/articulo?codigo=5846679

Portellano Pérez, JA (2014). Dysgraphia: concept, diagnosis and treatment of writing disorders. Editorial CEPE. https://elibro.puce.elogim.com/es/lc/puce/titulos/153574

Intriago, K. E. C., Rodríguez, L. M. A., \& Cevallos, L. A. T. (2021). Specific learning difficulty: autism, dyscalculia, dyslexia and dysgraphia. International Research Journal of Engineering, IT \& Scientific Research, 7(3), 97-106. https://doi.org/10.21744/irjeis.v7n3.1539 
Ramírez, C. (2011). Learning problems at school. Pedagogical Horizons, 3(1), 43-51. Recovered from https://dialnet.unirioja.es/servlet/articulo?codigo $=4777933$

Rangel, A. (2017). Pedagogical guidelines for the inclusion of children with autism in the regular classroom and support for the teacher. Telos. Journal of Interdisciplinary Studies in Social Sciences, 19 (1), 88-89. Recovered from https://dialnet.unirioja.es/servlet/articulo?codigo $=6219223$

Richardson, A. J., \& Puri, B. K. (2002). A randomized double-blind, placebo-controlled study of the effects of supplementation with highly unsaturated fatty acids on ADHD-related symptoms in children with specific learning difficulties. Progress in Neuro-Psychopharmacology and Biological Psychiatry, 26(2), 233-239. https://doi.org/10.1016/S0278-5846(01)00254-8

Rizo, J. (2015). Documentary Research Techniques. National Autonomous University of Nicaragua, Managua, $\begin{array}{llll}\text { Matagalpa Regional } & \text { Multidisciplinary } & \text { Faculty. }\end{array}$ https://repositorio.unan.edu.ni/12168/1/100795.pdf

Rodríguez, C. (May 31, 2015). Neuro-scriptural system: The brain and writing. REDEM World Educational Network. https://n9.cl/5a4gv

Rojas, A., Contreras, A., Arévalo, M. (2011). Didactic intervention to promote the learning of mathematics in children with dyscalculia. Answers, 16(2), 5-13. Retrieved from https://dialnet.unirioja.es/servlet/articulo?codigo $=5364555$

Sánchez, J., Sánchez A., Pastor, V., Martínez, J. (2019). Teacher training for autism spectrum disorder. Sport TK: Euro-American journal of sports science, $8(2-1), \quad 60 . \quad$ Retrieved from https://dialnet.unirioja.es/servlet/articulo?codigo $=7148410$

Schneider, J. (2017). Learning styles and autism. Boletín Redipe, 6(11), 60. Recovered from https://dialnet.unirioja.es/servlet/articulo?codigo $=6275729$

Schunk, D. (2012). Learning theories. An educational perspective. Recovered from https://www.freelibros.me/libros/teorias-del-aprendizaje-una-perspectiva-educativa-6ta-edicion-dale-h-schunk

Scrich, A., Cruz, L., Bembibre, D., and Torres , I. (2017). Dyslexia, dysgraphia and dyscalculia: its consequences in the Ecuadorian education. Camagüey Medical Archive, 21(1), 766-772. Retrieved from https://www.redalyc.org/articulo.oa?id=211149710003

Tamayo, S. (2017). Dyslexia and difficulties in the acquisition of literacy. PROFESORADO Magazine of the curriculum and teacher training, 21 (1). https://recyt.fecyt.es/index.php/profesorado/article/view/58074

Teruel, J., Latorre, A. (2014). Learning disabilities: intervention in dyslexia and dyscalculia. Pulse: Education Magazine, (37), 299-301. Recovered from https://dialnet.unirioja.es/servlet/articulo?codigo=5823481

Woodcock, S., \& Vialle, W. (2016). An examination of pre-service teachers' attributions for students with specific learning difficulties. Learning and Individual Differences, 45, 252-259. https://doi.org/10.1016/j.lindif.2015.12.021

Woodcock, S., Hitches, E., \& Jones, G. (2019). It's not you, it's me: Teachers' self-efficacy and attributional beliefs towards students with specific learning difficulties. International Journal of Educational Research, 97, 107-118. https://doi.org/10.1016/j.ijer.2019.07.007 